\title{
The Tablighi Jamaat Movement Its Ideological Concept and Organizational Structure
}

\author{
Zulkhan Indra Putra \\ Researcher and graduate student in Conflict Analysis and Peace \\ Building at Jamia Millia Islamia University, New Delhi - India. \\ Email: zulkhanip@yahoo.com
}

\begin{abstract}
The author discusses the nature of the Tablihi Jamaat, an India-based Islamic movement which in the past decades has witnessed organizational transformation by becoming the transnational Islamic movement active in many parts of the world. The author pays attention to the characteristic of religious ideology of the organizational pattern of Tablighi Jamaat. He argues that a strong organizational commitment and voluntarism among the members of the Tablighi Jamaat have had a profound impact on the enduring Tablighi Jamaat activities. Yet, ideologically, unlike other Islamic movements such as Ikhwanul Muslimin or Hizbut Tahrir whose ideological foundations are nurtured through written communication and speech based-congregational preaching, the Tablighi Jamaat has utilized direct and personal approach in delivering the messages of Islam to the communities. Keywords: Tablighi Jamaat, religious Ideology, transnational organization, the Islamic movement.
\end{abstract}

\section{ABSTRAKSI}

Penulis mendiskusikan tentang gerakan Jamaah Tabligh, sebuah gerakan Islam asal
India yang dalam beberapa dekade terakhir ini bertransformasi menjadi gerakan Islam internasional yang aktif di pelbagai belahan dunia. Penulis memberikan perhatian pada karakteristik ideology keagamaan dan bentuk keorganisasian Jamaah Tabligh. Penulis berpendapat bahwa komitmen yang kuat dan sikap kerelawanan di kalangan anggota Jamaah ini memberikan dampak kuat pada berlangsungnya kegiatan dakwah Jamaah Tabligh. Tidak seperti organisasi yang lain, sebut saja Ikhwanul Muslimin atau Hizbut Tahrir yang mendasarkan model dakwahnya pada materi-materi tertulis dan dakwah keorganisasian, Jamaah Tabligh melakukan banyak pendekatan personal dalam menyampaikan pesan-pesan Islam (dakwah) kepada komunitas-komunitas Muslim.

Keywords: Jamaah Tabligh, ideologi keagamaan, organisasi transnasional, gerakan Islam.

\section{INTRODUCTION}

Tablighi jamaat has been viewed to be an apolitical and less-institutionalized transnational organization. However, present evidence suggests that it is considered as the world's largest transnational Islamic movement. ${ }^{1}$ This paper sets out to examine this phenomenon in light of the history, ideology, and the organizational perspective of the movement. The term transnational Islamic movement refers to interactions and multiple ties connected Muslims accross the borders of modern nation states. In fact, the transnational attribute embedded in such religious activism could be properly understood only in its relations with the Westphalian system of modern 
nation state concept in which the Catholic Church had gradually lost its influence among local churches. While, on the other side, Islam has become a global religions since its inception. Beside Tablighi Jamaat movement, there are several Islamic movements which are operating transnationally, such as Ikhwanul Muslimin and Hizbut Tahrir whose concept of ummah has become a base for its political entity, or Gulen movement of Turkey that is working largely on transnational humanitarian activism as a base for its socio-cultural entity. By all accounts, the area of transnational religious movement is still becoming a fertile ground awaiting for many more studies.

Today, the Tablighi Jamaat (Jamaah Tabligh, as largely known in Indonesia) is a visible presence all over the world and has expanded its network even in remote locations and far from other major population centers. This movement gradually expands from local to national to a transnational movement and now it is operating in 165 countries $^{2}$ with significant influence in many majority Muslim as well as non-Muslim majority countries in Western and Eastern Europe and North America. Its annual assembly, held in Tongi, Bangladesh, was larger than any other Islamic organization's assembly around the world except for the Hajj. It is estimated that its members goes between 12 to 80 millions. However, its global presence and increasingly growing influence in both majority Muslim and nonMuslim countries makes the Tablighi Jamaat becoming the most dynamic Islamic group in the world, with scant regard for the logic of loyalties of national territory.

The concept of motivation and organizational commitment within Islamic organiza- tion has not received adequate attention in the literature and research. This is so, especially, in the transnational Islamic organizations context. Given the growing intensification of transnational religious networks, more notably of the Tablighi Jamaat, it is becoming increasingly necessary to study the concept of motivation and organizational commitment in different religious movements. ${ }^{3}$ This concept has led me to take an interest in the concept of commitment and motivation within the Tablighi Jamaat. It seems to be particularly interesting to analyze it in the ideology of the movement, which spurs its activities. From this standpoint, Tablighi Jamaat can be held up as an outstanding example.

This paper examines the phenomenon by looking at the concept of motivation and commitment held within the Tablighi Jamaat and will end with some observations about organizational perspectives. The paper will focus on three related questions: 1) what are causes that make the Tablighi Jamaat acquires significant growth? 2) what are the objectives of the movement? and 3) what are the ideological concepts which stimulate the members to take contributions to the organization and how it is portrayed through an organizational perspectives? This paper is thus organized as follows. I outline the interlinked primary resources, such as historical background, objectives, and ideology, which are necessary preconditions for a movement to sustain and expand. These preconditions are observed in order to be in line with the definition of social movement, as MSA Rao demonstrates that a social movement is an organized attempt on the part of a section of society to bring about either partial or total change in society through collective mobiliza- 
tion based on ideology. ${ }^{4}$

The second section will find out the organizational structure that drive the Tablighi Jamaat movement since an observation of the organizational perspectives is essential for understanding its survival and achievements. This part will highlight the organizational theories corresponding to this movement. This section thus explores the organization and structure of the jamaat, and how it becomes a successful transnational movement.

\section{TABLIGHI JAMAAT MOVEMENT: ORI- GINS AND IDEOLOGY The Genesis of the Movement}

The history of the Tablighi Jamaat, best known as the sufi-background movement, has generally been understood through doctrinal works produced by its founding-leaders. Tablighi Jamaat literally means a "conveying group". It basically fused some aspects of sufism with strict adherence to shariah combined with practical da'wah activities. It is an apolitical and less institutionalized, having no formal organizational structure, devotional movement whose primary aim is to bring about reforms into Muslim individuals, stressing individual faith, spiritual development, and introspection. As a Sufi-background movement, Tablighi Jamaat consistently maintains its distance from political practices. It concentrates more on devotional life collaborated with da'wah in terms of missionary duty. It is from this standpoint that Tablighi Jamaat has been described by scholars and observers as a peaceful and law abiding movement. As a matter of fact, even Pakistani militay officers allow the Tablighi to preach in their barracks. ${ }^{5}$

Tablighi Jamaat emerged from Deobandi movement active in South Asia. Maulana Ilyas Kandahlawi (1885 - 1994), the graduate of Deoband madrassah in 1910, launched the movement in the early twentieth century as a peace, independent, and voluntarily movement. Maulana Ilyas was known for his knowledge of Islam and his inclinations towards sufism. Being established as a response to the Hindu revivalist movement in India, which strived to reconvert Muslims who had converted to Islam in the period when Muslim political power took control of the region ${ }^{6}$ as well as the presence of Christian missionary agenda sponsored by the British colonials, the movement avoided to resort to direct confrontations with Hindu and Christian groups. It refused the use of violence and has eventually been directed towards more apolitical and adopting quietistic peaceful model based on the idea of inner individual transformation, a mission the movement continues to the present day.

Following the onset of mass politics, the first quarter of the twentieth century was a period of intense political mobilisation accross the Indian subcontinent. Mewat, southwest of Delhi, the region where Tablighi Jamaat was founded, was one of the target regions of Hindu reconversion movements, and the Tablighi Jamaat was formed at a time of intense rivalry between Muslims and Hindu in India. ${ }^{7}$ Realizing the particular situation, instead of relying merely on the method of traditional Islamic schooling, Maulana Ilyas initiated a method of learning which is more practical in pattern, inviting and encouraging even the less educated Muslims to leave their environment and begin preaching to others. Tabligh, he argued, was incumbent not only on the learned but also on every Muslims. ${ }^{8}$ As a conse- 
quence, in the mid-thirties, the Tablighi movement spread widely in Mewat and became very popular. ${ }^{9}$ The ideology of the movement, then, cultivated to revive Islam in response to the cultural onslaught of the colonial British occupation.

Following the demise of Maulana Ilyas in 1944, Maulana Muhammad Yusuf (19171965), Maulana Ilyas' son, took control the leadership of the movement. Under his leadership, the movement dramatically reached its peak through which he toured throughout subcontinent. This movement further increasingly spread to Southeast Asia, Africa, Europe, and North America. During this time, also, the conventions began to be held regularly in various parts of the subcontinent and from his time onwards the participants are moving out over the whole world, on foot, by bus, by train or airplane or any other suitable means. ${ }^{10}$ While under the leadership of Maulana In'amul Hasan (19651995), its worldwide activities increased dramatically, perhaps it is in line with the increasing Indo-Pakistani diaspora in many countries. ${ }^{11}$ However, despite its massive expansion, this movement hardly gets governments' suspicion. The reason is, it is believed, because this movement always maintains its apolitical stance.

Probably, the most important things of this movement, once Maulana Ilyas suggested to an All-India Conference of Ulama and the Muslim Political Leaders at Delhi in 1944, when he distinguished between two different techniques to be adopted by the Indian Muslim community. First, acquire power, and then prevail upon the people by force. Second, strive among the people with heart and soul and then employ the consequent favours of God. ${ }^{12}$ In here, he chose the second and this stance was maintained by his successors until present day.

In the context of Indonesia, the Tablighi Jamaat penetrated to the country via Medan and Jakarta in 1952, after which it spread rapidly all over the country. Today, the movement is a visible presence all accross regions in Java, Sumatra and Madura, and has been expanding its networks to other islands such as Kalimantan, Sulawesi, Nusa Tenggara, the Mollucas and even in the West Papua. It is safe to say that no region in Indonesia where the movement doesnt set its foot conducting da'wah activities. Yet, what is truly interesting about the expansion was how the movement successfully spreading using the same standard, keeping the unity and the consistency of its identity in the middle of different various local culture, language, ethnicity, and history.

\section{The Doctrinal Roots and Objectives}

The Tablighi Jamaat was founded in 1925 and it started its works as a reform movement in the district of Mewat, southern Delhi. It emerged out of Deobandi sub-school with predominant using of Hanafi school of jurisprudence. However, no particular jurisprudence or interpretation of Islam has been dominating since the inception of the movement. Therefore, every member is allowed to follow his own school of jurisprudence as long as it does not deviate from Sunni Islam.

This movement, like any other Muslim movements, is premised on the teachings of the Quran and the Hadith (prophetic traditions), the life of the Prophet Muhammad PBUH and his companions. They believed that as Prophethood was ended with the sending of Prophet Muhammad PBUH, it is thus the obligation of all Muslims coming 
after the Prophet to call people to Allah. Here, any Muslim should follow the Quranic teachings to call people to the way of Allah with wisdom and fair exhortation and reason with them in the better way. Through this movement, Maulana Ilyas called every committed believer to leave his home and give up his occupation for a period of time, in order to rehearse the faith on the pattern - in his opinion - of the life of the companions of the Prophet PBUH, away from the affairs and interests of everyday life.

Its slogan - Oh Muslims, Become Muslims -, coined by Ilyas Kandahlawi himself, demonstrates that the movement's main point was to convert not those of non-Muslim but rather of Muslims. Its main objective is to reach all Muslim societies at the grassroots levels in order to bring them to the pristine perfection of Islam at its foundational moment and follow the piety and practice of Prophet Muhammad PBUH and his companions (shahabah). Tablighi Jamaat believes that the decline of Islam and Muslim religiousity started following the passing of the Prophet and the subsequent lost the prophetic ideal type, for the Prophet is not merely an individual who transmitted Islam but he also demonstrated a Muslim ideal way of life. ${ }^{13}$ It is thus also called a re-pietization organization. ${ }^{14}$

The objectice of the movement is to turn a muslim into a proper muslim (muhsin), who not only believes in God and prophetic traditions but also conducts and internalizes the values and norms of Islam in their daily life and activities. The Tablighi Jamaat believes that they are different from other muslims, whose faith they may regard as being incomplete. It is from this standpoint that the movement also introduces the distinction between ordinary believer (mu'min) and those who choose to live out a life of Islamic piety trough their good conducts (muhsin). ${ }^{15}$ The Tablighis portray ordinary muslims as those who merely perform duties and rituals without knowing the meaning of what they do. This is, in fact, one of the first internal discursive frontiers introduced by the Tablighi Jamaat in building their own identity and distinction. This notion is an important one in understanding why and how the Tablighi can be defined as a da'wah movement that seeks to bring muslims into their fold.

In terms of how the movement portrays Prophet Muhammad PBUH, in comparison to notions propounded by Muslim business leaders or politically inclined Islamic organizations who views the Prophet PBUH as a successful businessman and ruler, the Tablighi portrays the Prophet PBUH as an individual of an un-worldliness. They believe that those who follow the Prophet in the notion that he is an un-worldliness individual will come closer to loving him and understand his prophetic message. This particular worldview, however, largely serves as a discursive device for the Tablighi Jamaat's worldview and becomes the discursive formation of the movement.

In addition to the teachings of the Quran and the Hadith, the curriculum thought in the Tablighi Jamaat comprised of some works compiled by its founding-leaders, which has also been translated in full into Bahasa Indonesia, such as Himpunan Fadhilah Amal, Dalil-Dalil Enam Sifat Para Sahabat, Kehidupan Para Sahabat, and Fadhilah Sedekah. Himpunan Fadhilah Amal, a compilation of 7 works by Maulana Muhammad Zakaria, is the one that is most often referred to by the leaders and 
teachers of the Tablighi Jamaat in their sermons. It comprises of Fadhilah Al-Quran, Fadhilah As-Shalah, Fadhilah Az-Zikr, Fadhilah At-Tabligh, Kisah-Kisah Shahabah, Keruntuhan Umat Islam dan Cara Mengatasinya, and Fadhilah Ar-Ramadlan.

Maulana Ilyas, as a founder of the movement, developed fundamental principles of the Tablighi Jamaat, comprising of six principles based on the universal personal character of the companions of the Prophet PBUH. Those principles are the following:

1. Every Muslim should be able to recite shahadah in Arabic correctly (Kalimah)

2. Every Muslim should perform five daily prayers, and learn how to perform sholat perfectly (Five times daily prayers)

3. Every Muslim must learn the basic teaching of Islam and do dzikr (Ilm and Dzikr)

4. Every Muslim must respect other fellow Muslims (Ikramul Muslim)

5. Every Muslim must cultivate honesty and sincery, performing actions for the sake of Allah (Ikhlasun Niyyat)

6. Every Muslim must spend some times to travel from place to place to spread the words of Allah, sacrificing time, energy and wealth, following the footsteps of the Prophet for the sake of faith (Da'wat and Tabligh)

It is believed that the collective success of a Muslim community depends largely on certain activities such as internalizing the missionary spirit, acquiring basic knowledge of Islam and its dissemination to Muslims through mutual cooperation among them. Maulana Ilyas stressed this movement on purifying the Muslims to make them better Muslims who would set practical examples of Islam before other communities. By looking at this ideological background, Tablighi Jamaat is certainly not inventing a new feature of Islam. Not even to remake the world through restructuring key social, economic and political institution in society, rather to reshape individual lives and recreate Muslims in the form of true Muslims of pristine Islamic period. ${ }^{16}$ It is, thus, in this premise, the Tablighi Jamaat believes that bottom-up approach is the best way to achieving change.

It is said that the transnational movement presented by the Tablighi Jamaat is not always about religion. It is argued that sociologically, Muslims are attracted to the Tablighi Jamaat because many Muslims particularly from upper-middle class and below find themselves in the grips of disappointed modernity which can only be benefitted by few individuals. Islam for these Muslims thus provides comfort and a haven.

Since modernity brought about positive changes in society and improved human conditions, particularly in the West where benefits of modernity have been enjoyed the most. Unfortunately, minority groups like Muslims in the West hardly get their share socially and economically, while only a minority has enjoyed the positive outcome of modernity in the non-western parts of the world. ${ }^{17}$

\section{ORGANIZATIONAL PERSPECTIVE OF THE TABLIGHI JAMAAT Organizational Structure of the Movement}

Since its inception as of now, the Tablighi Jamaat does not require any formal bureaucracy and paid staff. It, however, depends largely on small groups (jamaats) of perhaps eight or ten people, who finance themselves, going out door-to-door inviting people to 
come to the mosques in which they began to preach the message of Islam. Participants are ideally organized in four ways; one day a week, one three-day period a month, one forty-day period a year, and one four-month tour at least once in a lifetime. ${ }^{18}$ While Tablighi Jamaat participants may also belong to professional institutions, sometimes the arrangement is made simple.

The movement adopts a form of an informal organization and keeps an introvert institutional profile. Keeping away from the media and avoid detail publication with regards to its activities and membership. Maulana Ilyas was not in favour of writing about the Tablighi Jamaat, probably because he believed that action and practice were the best method to effectively change minds. ${ }^{19}$ It also completely absent from the public opinions and controversial issues in order to avoid disputes that might be happen. As an organization, the Tablighi Jamaat asks no donation and largely depends its finance upon its senior members. It is because of the absence of formal registration, we hardly know the exact number of its members.

Organization activities are coordinated through the centres and headquarters, which they call markaz. Their international headquarter is located in southern Delhi, used to be called as Nizamuddin markaz. They also have their headquarters in every country to coordinate their activities. These markaz are voluntarily organized with self-financing from their own members. This is through those headquarters the movement continue to expand all over the world.

Self-financing trip (khuruj) is an inherent characteristic of participants in the Tablighi Jamaat. Everyone involved in the movement would voluntarily cover his own expenses during the preaching travel. In addition, to support its activities, there are also some senior members who donate to the movement. Organizational theorists argue that the success of a movement is highly dependent on contribution of "resourceful actors", because they have the capacity to contribute a significant part in achieving the goals of the movement.

\section{Theoretical Frameworks}

Through theoretical perspective, we would like to analyze what are the organizational mechanisms that explain why Tablighi Jamaat has captured the enthusiasm of millions of Muslims around the world. And in what ways do the financial mechanisms involved in funding the service projects promote the involvement, enthusiasm, and commitment of movement supporters? Two theoretical frameworks help to explain why the Tablighi Jamaat movement has been so successful both in India and internationally.

The first is the intrinsic motivation theory. In basic terms, motivation theory is defined as the reason someone does something. While in the term of the intrinsic motivation theory, it is the term of internal motives to the reason behind why someone does something. In comparison to extrinsic motivation theory, which stresses on external rewards such as pay-for-performances incentive devices (bonuses, gifts, etc.), intrinsic motivation is believed to show better compliance in the long run. Unlike the central tenet of modern economics, which held that individuals largely respond to monetary incentives or external motivation, intrinsic motivation suggests the members to act for the love of the activities and believes the rewards coming from his intrinsic belief. ${ }^{20}$ 
This theory is characterized by intense concentration and motivation that centers on the process and the goal. This theory enables a movement or organization to grow continuously.

In terms of the intrinsic motivation theory, Tablighi Jamaat has something to offer to its members: it provides Muslim identity, a sense of purpose and the meaning of life. The foundational texts of the movement play a crucial role in which it privileges the Prophet PBUH and his companions as the ideal prototypes for the Muslims. As it is stated in the prophetic tradition that whosoever follows the practice and lifestyle of the Prophet will come closer to loving the Prophet and understanding his prophetic message. ${ }^{21}$ It forges communities in which the members would experience self-satisfaction and a sense of fulfilment by following the piety, practice, and even lifestyle of the Prophet and his companions. This movement thus provides moral support and spiritual guidance. It also offers to the oppressed and marginalized masses the position of faithful members of the community of believers giving psychological encouragement.

In regards of the theory, we find that the members of the Tablighi Jamaat join this movement for their love of the activities characterized by this movement, such as travelling, calling people to the way of God, gathering with fellow Muslims, following the lifestyle of the Prophet, etc., giving them selfsatisfaction. In addition, they believe that such activities will give them a reward in the hereafter, as they believe that it is the duty for every Muslim to call people to God. This motivation, further, lead them to spend their time, energy and money to contribute the expansion of this movement.
The second is the organizational commitment theory, which focuses on movement intentions for gaining member motivation to provide necessary resources and the consequences on building loyalty to the movement, thus assuring its validity and growth. In the field of Organizational Behaviour, organizational commitment theory may be defined as the relative strength of an individual's involvement in a particular organization. It is a psychological state that binds an individual member to an organization. An individual will tend to adhere to the norms and conform to the values and expectations of those to whom he is committed. ${ }^{22}$

Researchers have been studying organizational commitment in its relations to many situational attitudes, characteristics and behaviors of employees. Moreover, Brigitte Charles-Pauvers and Zhongming Wang propound that there are three factors characterize commitments; a) A strong belief in and acceptance of goals and values of the organization, b) A willingness to make considerable efforts for the benefit of the organization, c) A high desire to remain a member of the organization..$^{23}$ It is defined as the strength of member's identification with a given organization. In accordance to the above finding, Putti, Aryee, and Ling, further observed that intrinsic motivation values relate more closely to organization commitment rather than extrinsic motivation values. ${ }^{24}$

Correspondingly, Tablighi Jamaat has its own concept that is derived from the Quran and sunnah. As a result, those within the organization who believe in Islam and follow the standard tenets of Islam tend to be more satisfied and more committed to the movement. As a result, they will have low intention to turnover out of the organization. 
From this background, we find the attractiveness of Muslims to join $T$

is because, for the members, self-improvement is very satisfying that through this movement they can make commitment to religion and valuing the travelling cultures.

The studies of organization have also highlighted that commitment has great impact on organization's performance. This is because a member with high commitment will identify the goals and values from his involvement in the activities and the member of the movement is thus willing to perform the duty. A committed person is loyal and involved, has a sense of belonging, a feeling that the group is an extension of the member and that the member is an extension of the group. ${ }^{25}$ Similarly, the members of the Tablighi Jamaat are willing to take the trip by their own money and so its senior members who continuously donate a large amount of money. Given the tradition of members' commitment in terms of giving time, emotional involvement, and finances to achieve movement goals, the concept of organizational commitment implies a strong tendency for working for internal development and goal achievements of the Tablighi Jamaat.

\section{CONCLUSION}

In summary, we can conclude that intrinsic and extrinsic motivation theory and organizational commitment theory provide a lens through which to view the Tablighi Jamaat and to explain why it is thriving. These theoretical tools, along with an analysis of the historical and ideological context in which the founder preached in India and an understanding of the Islamic concepts of selfimprovement provide insight into the beliefs, values, and social dynamics that are propel- ling this movement to international prominence.

In addition, the model of preaching adopted by the Tablighi Jamaat has located this movement to the position in stark contrast to its counterparts such as Ikhwanul Muslimin or Hizbut Tahrir, whose activities are highly dependent on written communication and speech based-congregational preaching. A direct approach with simple message and seeking a slow yet permanent transformation made Tablighi Jamaat a pleasant and non-threatening movement before the world.

Finally, there are some limitations in this study need to be considered. Firstly, the researcher does not involve quantitative research methods using big sample size. Secondly, generalizations of findings in this study obtained through interviews with only scant number of individuals. Lastly, the limited amount of variables may affect the findings. Therefore, it is for the next study to better use quantitative methods involving both Tablighi Jamaat participants and exparticipants to obtain more convincing results.

\section{ENDNOTES}

1 Muhammad Khalid Masud (ed.), Travellers in Faith; Studies of the Tablighi Jama'at as a Transnational Islamic Movement for Faith Renewal (Leiden: Brill, 2000), p. 15

2 Tablighi Jamaat, American Foreign Policy Council, p. 1. http://almanac.afpc.org/sites/almanac.afpc.org/files/ Tablighih20]amaat_0.pdf

3 Shail Mayaram. "Hindu and Islamic Transnational Religious Movement", Economic and Political Weekly, (2004), p. 80

4 Rao, M.S.A. (ed.). Social Movements in India, (New Delhi: Sage Publication India Pvt. Ltd., 2004), p. 19

5 Alex Alexieve. "Tablighi Jamaat: Jihad's Stealthy Legions," Middle East Quarterly, (winter 2005), pp. 3-1

6 It must be noted that the objective of the movement should not be misleading since this movement aims at strengthening the Muslims and not converting nonMuslims into Islam. 
7 Farish A. Noor. Islam on the Move: The Tablighi Jamaat in Southeast Asia, Amsterdam: Amsterdam University Press, 2012).

8 Barbara D. Metcalf, Tablighi Jamaat, in Richard C. Martin (ed.), Encyclopedia of Islam and the Muslim World New York: MacMillan, 2004), p. 671

9 Christian W. Troll, 'Two Conceptions of Da'wa in India: Jama'at Islami and Tablighi Jama'at', Archives de Sciences Sociales desReligions (1994), p. 120.

10 Ibid, p. 121

11 Barbara D. Metcalf, Tablighi Jamaat, in Richard C. Martin (ed.), Encyclopedia of Islam and the Muslim World (New York:MacMillan, 2004, p. 672.

12 Christian W. Troll, 'Two Conceptions of Da'wa in India: Jama'at Islami and Tablighi Jama'at', Archives de Sciences Sociales desReligions (1994), p. 122.

13 Farish A. Noor, p. 67.

14 Tablighi Jamaat, American Foreign Policy Council, p. 1.

15 Farish A. Noor, p. 75.

16 Ali, Jan A. "Tablighi Jamaat: A Transnational Movement of Islamic Faith Regeneration". Accessed from: http:// ejeps.fatih.edu.tr/docs/articles/67.pdf

17 Ibid.

18 An interview with Capt. Erwin Ruliansyah, an Indonesian participant of the Tablighi Jamaat and former Jet Airways senior commander pilot, now living in Hongkong.

19 Muhammad Khalid Masud, (ed.), Travelers in Faith: Studies of the Tablighi Jamaat as a Transnational Islamic Movement for Faith Renewal (Leiden: Brill,2000), p. 80.

20 Dana George, 'About Intrinsic and Extrinsic Motivation', accessed from http://www.ehow.com/ about_4616875_intrinsic-extrinsic-motivation.html, on September $30^{\text {th }} 2010$.

21 Farish A. Noor, pp. 74-75.

22 J. H. Amernic, 'Organizational Commitment: Testing Two Theories', Relations Industrielles Journal (1998), p. 319.

23 Brigitte Charles-Pauvers and Zhongming Wang, 'Organizational Commitment: Examining the Case of China', Management International Review, Springer, 2002, p. 159.

24 Wahibur Rokhman, The Effect of Islamic Work Ethics on Work Outcomes, Electronic Journal of Business Ethics and Organization Studies, vol. 15, no. 1, 2010), p. 22.

25 Helen Rose Ebaugh. The Gullen Movement: A Sociological Analysis of A Civic Movement Rooted in Moderate Islam (London: Springer, 2010), p. 8.

\section{BIBLIOGRAPHY}

Alexieve, Alex. 2005. Tablighi Jamaat: Jihad's Stealthy Legions. Middle East Quarterly, pp. 3-1. Accessed from: http://www.newageislam.com/radical-islamism-andjihad/tablighi-jamaat-jihad-s-stealthy-legions/d/ 34588
Ali, Jan A. "Tablighi Jamaat: A Transnational Movement of Islamic Faith Regeneration". Accessed from: http:// ejeps.fatih.edu.tr/docs/articles/67.pdf

Amernic, J. H. 1983. "Organizational Commitment: Testing Two Theories", Relations Industrielles, pp. 319-343

Charles-Pauvers, Brigitte and Zhongming Wang. 2002. 'Organizational Commitment: Examining the Case of China', Management International Review, Springer, pp. 155-168

George, Dana. 2010. 'About Intrinsic and Extrinsic Motivation', accessed from http://www.ehow.com/ about_4616875_intrinsic-extrinsic-motivation.html, on September $30^{\text {th }}$.

Ebaugh, Helen Rose. 2010. The Gullen Movement: A Sociological Analysis of A Civic Movement Rooted in Moderate Islam. London: Springer

Masud, Muhammad Khalid, (ed.). 2000. Travellers in Faith Studies of the Tablighi Jamaat as a Transnational Islamic Movement for Faith Renewal. Leiden: Brill.

Martin, Richard C (ed.). 2004. Encyclopedia of Islam and the Muslim World, New York: MacMillan.

Mayaram, Shail. 2004. "Hindu and Islamic Transnational Religious Movement", Economic and Political Weekly, pp. 80-88

Noor, Farish A. 2010. "The Arrival and Spread of the Tablighi Jama'at In West Papua (Irian Jaya), Indonesia." S. Rajaratnam School of International Studies Working Paper Series No. 191, 1-31. 2012. Islam on the Move: The Tablighi Jamaat in Southeast Asia. Amsterdam: Amsterdam University Press.

Rao, M.S.A. (ed.). 2004. Social Movements in India, New Delhi: Sage Publication India Pvt. Ltd.

Rokhman, Wahibur. 2010. The Effect of Islamic Work Ethics on Work Outcomes, Electronic Journal of Business Ethics and Organization Studies, vol. 15, no. 1

Saberwal, Satish, and Mushirul Hasan (eds.). 2006. Assertive Religious Identities: India and Europe, New Delhi: Manohar Publishers \& Distributors

Troll, Christian W. 1994, 'Two Conceptions of Da'wa in India: Jama'at Islami and Tablighi Jama'at', Archives de Sciences Sociales desReligions

Tablighi Jamaat, American Foreign Policy Council, p. 1. Accessed from: http://almanac.afpc.org/sites/ almanac.afpc.org/files/Tablighih20]amaat_0.pdf 